\title{
Parliamentary Democracy and Representation of Women: A Comparative Analysis of Sri Lankan and Malaysian Stances
}

\author{
Mohammad Agus Yusoff (Corresponding Author) \\ School of History, Politics and Strategic Studies, Faculty of Social Sciences and Humanities \\ Universiti Kebangsaan Malaysia, UKM Bangi 43600, Selangor, Malaysia
}

\author{
Athambawa Sarjoon \\ PhD Candidate, School of History, Politics and Strategic Studies, Universiti Kebangsaan \\ Malaysia \& Department of Political Science, University of Peradeniya, Peradeniya-20400, Sri Lanka
}

Shameer Othman

PhD Candidate, Faculty of Human Ecology, Universiti Putra Malaysia, Serdang, Malaysia

\author{
Doi:10.5901/ajis.2016.v5n1p111
}

\section{Abstract}

\begin{abstract}
Although both Sri Lanka and Malaysia have experienced a parliamentary democracy introduced by the British colonial ruler, there are disparities in terms of the representation of women in parliament. Democracy assures women's roles in politics, as well as their rights to represent in government apparatus, including parliament. However, the majority of democratic countries in the Global West have succeeded, while the majority of those in the Global South have failed in this regard. This particular research comparatively analyzes women's representation in parliament-the higher legislative and decision-making body-in Sri Lanka and Malaysia, both have strictly been following a democratic path in governance from their independence. The findings of the study reveal that the country-based different contextual factors have influenced women's roles in active politics, and their position in parliament representing the public as equally as that of men. This study is descriptive and interpretive in nature, and only secondary data were applied for the analyses of the nature of women's representation in parliament in both countries.
\end{abstract}

Keywords: Parliament democracy, women representation, Sri Lanka, Malaysia

\section{Introduction}

Similar to many other nations in Asia, both Sri Lanka and Malaysia have experienced the severe impact of colonialism, especially that imposed by the British rule. Although British colonialism has caused negative outcomes in terms of economic development, ethnic relations and national integration, both countries started to experience the taste of modern democratic concepts, including universal franchise, representation and parliament democracy, during this era.

There are differences and unique features in both Sri Lankan and Malaysian experiences of parliament democracy, but both have a number of similarities in terms of their societal set up, and the experience of state cum nation-building process. Generally, both are ethnically plural, but one group forms the absolute majority in the former; while one group forms a simple majority in the latter. This has led to varying ethnic group relations in societal and political levels in both countries: a clear nomination of absolute majority, and a continued fight to be dominated by a simple majority, respectively. In the context of Sri Lanka, there is no competing ethnic composition among the ethnic-majority and ethnicminorities. However, in the context of Malaysia, there are balancing and competing forces in terms of ethnic groups. This ethnic composition in these countries has challenged the exercise of parliament democracy in various ways. Sri Lanka has severely suffered in terms of building national integration, which led minorities to mistrust the parliament democracy, and has pushed them to mobilize and advocate for more power and autonomy in their predominant areas. Even though Malaysia has experienced ethnic and separatist struggles in its post-independence era, it was able to build a balancing state and a parliament democracy.

Both countries have opted for a long-term democratization process, and have gained their independence in a decade gap period (Sri Lanka in 1948; and Malaysia in 1956). However, women's representation in parliament in both countries has been at a lower level compared to other countries throughout the world and in the regional levels, and also 
compared to countries that practice non-democratic and non-parliamentary systems of government. Although women were given voting rights, and constitutions allow them to be involved in politics as equally as their male counterparts, their representation in parliaments in both countries has not yet exceeded 10 percent. The puzzle of this comparative study is why Malaysia and Sri Lanka, in their regional settings, have not elected more women to represent national parliaments, though both countries have been strongly practicing parliamentary democracy, and both have similar ethnic and political contexts? This study attempts to examine the level of women's representation, and the factors that limit women representation in parliament, of both countries, on a comparative perspective.

Studies of political activity and leadership development have generally tended to neglect women in many societies. Only in the last few years have such studies been undertaken in the field of political science. However, many studies conducted in the selected two countries were time limited and subject oriented. Most of them focused on the public political life and role of women, their roles in party politics, and the subjective matters that they represent in legislative bodies. On the contrary, the major objective of this study is to explore the nature and extent of women's representation in parliament in terms of number, and identify the key factors that impact the position of women's representation in parliament, of the two selected countries. The remainder of this paper is divided into four major parts, along with the conclusion. The following part reviews the nature of women's roles in parliament democracy, as well as their representation in parliament in general. The subsequent two parts review the nature of women in politics and their representation in parliament in the selected two countries: Sri Lanka and Malaysia. This review is followed by recommendations to improve women's representation in parliament. In this study, only the representative house, i.e. the upper house in Malaysia, and the central parliament in Sri Lanka, have been considered for analysis. This study is descriptive and interpretive in nature, and only the secondary data were used for the analyses of the nature of women's representation in parliament in both countries.

\section{Political Women, Parliament Democracy and Women Representation}

Politics has always coupled with men throughout history. In most of the ancient literature, the veteran philosophers, thinkers and writers have connected politics as an act related with men, and they mostly used masculine terms such as "he" and "his" in political writings and discourse. They failed to denote gender balancing terms such as "he" or "she," and the role of women in politics. Women were alienated from political discourse until the later part of the $19^{\text {th }}$ century, and they were not given political rights, the most important of which are the right to vote and the right to be represented in legislative and executive arms of government. Traditionally, political resources of women have been weaker than those of men. Women as a group used to have less education, a lower self-reported interest in politics, and a low labor force participation, compared to men. Women were confined to family and household, where daily life had little to do with politics. Initiatives to accommodate women and their rights within the political system and representative democracy were only considered with the mobilization of organized women movements in the later part of the $19^{\text {th }}$ century in Europe, which later expanded throughout the world. Despite efforts taken over the centuries by women and men, the recognition and the exercise of women's political, economic and social rights is by no means equal to men. Decision-making and priority setting in political and economic affairs remains largely in the hands of men.

Parliament democracy is a dominant concept in political discourse, and has been identified as the best form of governance around the world. It is the best political mechanism, and a powerful tool of legitimization of actions of government, that can not be questioned by anyone. The Oxford English Dictionary has simply defined democracy as "a form of government or rule by the people in which the sovereign power resides in the people as a whole and is exercised either directly by them (as in the small republics of antiquity) or by officers elected by them". Under parliament democracy, political authority is presented to representatives in the parliament as a delegated power brought into existence by the expressed will of the people. Here, the sovereign power ultimately resides with the people and that the form of government gives expression to the will of the people. The ultimate sovereign power must be given expression in some representative body to which that power is delegated. The national parliament (referred to in different names) is "sovereign" because it expresses the delegated power of the people, and is legitimately so because it is "representative" of the people's will. The parliament is a sovereign legislative body that makes laws, which bring general goods for the entire public (Hirst, 1988).

Democracy as a concept is rooted with the ancient Greek though the notion of "direct democracy": a process in which all citizens of the Greek city-states participated in the government activities themselves while representing themselves. The concept was then transformed into another form when state territory and population expanded, referred to as "indirect democracy", or a "representative democracy." Under this kind of democracy, the public are represented in 
governmental affairs through the representatives elected, appointed or nominated by them. An absolute form of representative democracy has emerged from the evolution of the parliamentary system in Britain. Today, the majority of sovereign states in the world practice the representative government system, and most of them exercise parliament democracy in collaboration with some ideologies such as socialism, Marxism and liberalism etc. A popular modern notion of democracy is given by former America President Abraham Lincoln as "the government of the people by the people and for the people."

Democracy as a concept considers all people or citizens equal, without any bias on the basis of gender, race, ethnicity, religion etc. Therefore, parliament democracy insists equity in women's representation in parliament. The seed of democracy lies in the principle that the legitimacy of the power to make decisions about people's lives, their society and their country should derive from a choice by those who will be affected (Ballignton \& Karam, 2014). However, for many centuries, the basis of this legitimacy was limited and many were excluded from making a choice: slaves, people of color, ethnicity, indigenous people and overwhelmingly, women who share roughly an equal portion in the world's total population. As Ballignton (2014) mentioned, an essential tenant of any democratic framework is the principle of human rights, including the granting and exercise of political rights of both men and women.

As a criterion of political representation, gender is usually regarded as a latecomer, often in relation to formal gender quotas. However, as Nagel emphasis, when gender does not mean women, but simply gender, it is evident that gender has been criterion from the start. Following the introduction of representative democracy, male citizens assumed an exclusive right to political representation, and they kept the privilege for a long time (refereed by Raaum, 2005:874). Political representation is a legislative recruitment that refers to the process of selecting those individuals who eventually serve in legislative bodies. This is a process that refers to a set of three hurdles. An individual must select himself or herself so that then he or she can be selected by the party, and finally, he or she must be selected by the voters. Eventually, all countries are at the outset of this process, though when the Members of Parliament (MP) have been selected, the average is only 15 percent female (Matland, 2004:02). In the beginning of the $21^{\text {st }}$ century, over 95 percent of all countries have granted the two most fundamental democratic rights (for all citizens): the right to vote and the right to stand for the election that ensure the gender equity in representative democracy. New Zealand was the first country to give women the right to vote in 1893, and Finland was the first to adopt both fundamental democratic rights in 1906 (Shvedova, 2005:34). In 2012, 190 countries among 193 had some form of functioning representative parliament, accounting for over 46,000 representatives (Power, 2012).

According to the Inter-Parliament Union (2016), the world's average percentage of women's representation in parliament was only 17.2 percent in 2008. This position increased from 19.25 percent in 2012, to 22.7 by the end of 2015 . Similarly, the world's average percentage of women's representation in the lower houses of parliaments was 22.8 by the end of 2015. Women's presence in parliaments around the world is a reality that impacts the social, political and economic fabric of nations on a global scale. Yet, their accesses to important legislative structures, learning how to work within them, and the extent to which they impact on and through them, remain serious challenges. A team of editors of the handbook, Women in Parliament: Beyond Number (2014) has identified several significant challenges women have been facing in their active role in politics and to increase their political representation in parliament and other legislative bodies throughout the world. These challenges can be grouped into (1) political obstacles, (2) socio-economic obstacles and (3) ideological and psychological hindrances. The first group comprises: masculine model of politics, lack of party support, cooperation with women's organizations, and electoral system. The second group comprises: the feminization of poverty and unemployment, the dual burden, and the lack of education and training. Finally, the third group comprises: traditional role, lack of confidence (of women), the perception of politics as "dirty" and the role of the mass media.

It is noteworthy that any kind of true democracy has to include principles of gender equality, rights and nondiscrimination of women and men in all spheres of life. Therefore, the political system of any democratic country must ensure that both women and men have sufficient opportunities to participate and represented in political affairs and institutions. The two countries, namely, Sri Lanka and Malaysia, selected for this research have a number of similarities in terms of socio-cultural and political conditions. Both were under the colonial rule of Britain, and have gained independence within a decade period (1948 and 1956 respectively). The principles of parliamentary democracy, which are in practice in these two countries, were introduced by the British rulers. Therefore, both countries are still in the path of parliament democracy, which strongly believes in electing or selecting representatives through democratic means. Although women's roles in politics in both countries have also given them political popularity, the representation of women in parliament has been limited in both countries compared with the countries in the developed and developing world. Sri Lanka can proudly claim that it is the first country that introduced universal franchises in the Asian context and elected the first woman Prime Minister in the world, but women's roles in active public politics remain rather limited. 
Therefore, it could not increase women's representation in parliament, the national law-making institution, at least up to six percent in its 85-year journey of representative democracy. However, in its journey of parliament democracy, which was started even later than that of Sri Lanka, Malaysia has been forefront to Sri Lanka in electing more female representatives in the national parliament.

\section{Women Representation in Parliament in Sri Lanka}

Sri Lanka is famous for women in its politics after it was the first country recorded to have elected a female Prime Minister in 1960. However, it was experiencing universal suffrage from 1931, with very low female representatives in parliament. When Mrs. Srimavo Bandaranaike, the widow of late Prime Minister, SWRD. Bandaranaike (1956-59) was elected as the country's first female Prime Minister in 1960, Sri Lanka received the world's attention. Mrs. Srimavo Bandaranaike made tremendous impacts in Sri Lankan politics, and even in politics on a global scale. She was the first female Prime Minister in the world history of parliamentary democracy. She was elected three times as Prime Minister of Sri Lanka, and had served on that position for over 18 years (1960-65, 1970-77 \& 1994-2000). At the same time, she became popular among the third world countries by strongly supporting and closely working with the Non-Align Movement. For nearly two years she led that movement during the Cold War period. However, her political leadership and popularity had not supported much to increase women's involvement in active politics, as well as their representation in parliament. During her active political career, she was unable to increase women's representation in parliament to a considerable level, even though she was fielding more women in the elections, and recommending more women to be appointed as Members of Parliament through national lists. She was also unable to increase women's representation, even in her cabinets.

The daughter of both Mr. and Mrs. Bandaranaikes, Mrs. Chandrika Kumaratunga was elected as Prime Minister of Sri Lanka, and later elected as Her Excellency President of Sri Lanka in 1994. She was reelected to the Presidency and served in that position for about 11 years. From November 1994 to August 2000, the two highest powerful political positions in Sri Lanka, the President (head of the state) and the Prime Minister (head of the government) were filled up by two strong women (mother and daughter). For nearly one third of the post-independence period, Sri Lanka's government was headed by female leaders.

Sri Lanka's constitution has guaranteed women's political rights, and there was no provision to prevent or limit women in being involved in politics, and being represented in legislative bodies and political institutions. But those provisions did not pave the way for women to be actively involved in politics, and to be highly represented in legislative bodies, especially in parliament. Table 1 illustrates women's representation in the legislative bodies in Sri Lanka from 1931 to present (2016). Compared with many countries, especially with Malaysia, women's representation in parliament is very low in Sri Lanka.

Many factors have contributed to the low level of women representation in parliament in the Sri Lankan context. Basically, the type of electoral system in a country is most important in ensuring women's representation in parliament and sub-legislative bodies. When Sri Lanka gained universal franchise, it practiced a territorial representative system. There were 50 constituencies in 1931, and it was increased to 160 in the 1970s. However, whenever the colonial and Sri Lankan rulers increased the constituencies, they did it only according to the need to accommodate the caste and ethnic differences. However, they failed to ensure that women's representation was equal to that of men, through any means. Even though there were provisions to appoint Members of Parliaments (MPs) by the Governor or Governor General of Sri Lanka under the Donougmore (1931) and Sollboury (1947) constitutions, only six women were appointed on this basis during the forty-year period (1931-70) (Kearney, 1981:740). In fact, the Sri Lanka Freedom Party (SLFP) is the largest and most popular party for socialism and democracy in Sri Lanka. However, during its tenure in the government, it could not adopt any policy provision in the electoral system to increase female members to the national parliament.

From 1978 onward, Sri Lanka has been practicing Proportional Representative (PR) system. However, it does not have any meaningful or systematic arrangement or provision to ensure electing considerable number of women representatives in the parliament. To date, no election produced more than six percent of women representatives to the parliament, partly due to the weakness in the electoral system itself, along with other barriers. The present electoral system has a mechanism to appoint 29 representatives through a National List to the parliament. It would be shared among parties according to the proportion of the vote they gained nationally in the parliamentary election. Here, the party leader and the hierarchy of the party have the authority to select and nominate nationalist members to the elections commission. However, most of the parties appoint male representatives through this system, and they use this number to bargain with other coalition parties to obtain their support to form a government and sustain in power. In fact, this National List option is one of a good means to increase women's representation in parliament, at least to a certain extent, by 
appointing more women through this National List.

Among the main factors that caused the low representation of women in Sri Lanka's parliament is the absence of a women quota system through constitutional provisions or party policies. Several proposals on quotas for women were made in Sri Lanka between 1998 and 2000, but none of them were successful. A proposal for a twenty-five percent quota for women in local bodies, for example, was dropped in the draft constitution presented to parliament, but withdrawn in 2000. It was reported that minority political party leaders mostly opposed the quota system because of the difficulties in finding female candidates. In 2001, calls for quotas were renewed. Hema Ratnayake, the Minister of Women's Affairs at that time, had declared that her People's Alliance government will draft legislation to provide a minimum of 25 percent representation of women in all elected bodies: from the national parliamentary level, to village councils. However, to date, this has not been achieved. According to the Inter-Parliament Union (2016), Sri Lanka is in the lowest stance in its regional setting (South Asia) in terms of providing representation to women in the parliament. At the end of 2015, women representation in parliament was highest in Nepal (29.4\%), followed by Afghanistan (27.7\%), Pakistan (20.6\%), Bangladesh (20\%), India (12\%), Bhutan (8.5\%), and Maldives (5.9\%) in South Asian context (IPU, 2016).

As Kearney (1981) and Liyanage (1999) indicate, all major political parties in Sri Lanka have for many years been maintaining women sections or societies, but the powers and effectiveness of these sections have always been questioned. These sections are only active during elections, and are not much effective for acting as instruments to enhance more women to higher levels within the parties and the legislative bodies. All parties use women sections mainly to gain more votes in the elections. In fact, most of the party's supreme body in Sri Lanka has been filled with male members. Therefore, women have little voice within the parties' structures. At the end of 2015, according to the Elections Commission, no party is headed by women among the 64 recognized political parties in Sri Lanka.

On the other hand, it is found that lack of proper training for women has also contributed for the low representation of women in the Sri Lankan parliament and other local government bodies. Most of the women represented at the parliaments were either widows or entered parliament through the support of family members being in parliament. Women have rarely entered parliament through local politics and obtained training from there. The woman President and the women Prime Ministers in Sri Lanka entered into politics because of the assassinations of their husbands rather than entering through local politics. Most of the party's structures have no mechanism to include many of the women into active politics and to increase their representation in parliament.

Table 1. Women representation in Sri Lanka Legislatures ${ }^{1}$ (1931- 2015)

\begin{tabular}{|c|c|c|c|}
\hline Period & Total members & Women members & Percentage \\
\hline $1931-1936$ & 58 & 02 & 3.44 \\
\hline $1936-1947$ & 58 & 01 & 1.72 \\
\hline $1947-1952$ & 101 & 03 & 2.97 \\
\hline $1952-1956$ & 101 & 02 & 1.98 \\
\hline $1956-1960$ (March) & 101 & 04 & 3.96 \\
\hline 1960 (March- June) & 157 & 03 & 1.91 \\
\hline 1960 (June) -1970 & 157 & 03 & 1.91 \\
\hline $1970-1977$ & 157 & 06 & 3.82 \\
\hline $1977-1989$ & 168 & $05(11)^{\star}$ & $2.97(6.54)^{\star}$ \\
\hline $1989-1994$ & 225 & $11(13)^{\star}$ & $4.88(5.77)$ \\
\hline $1994-2000$ & 225 & 12 & 5.33 \\
\hline $2000-2001$ & 225 & 09 & 4.00 \\
\hline $2001-2004$ & 225 & 10 & 4.44 \\
\hline $2004-2008$ & 225 & 12 & 4.90 \\
\hline $2010-2015$ & 225 & 13 & 5.8 \\
\hline $2015-$ & 225 & 11 & 4.9 \\
\hline
\end{tabular}

*The women elected at the elections are 05 and 11 respectively; however, 11 and 13 women served during these parliament periods, respectively.

Source: Inter Parliament Union, 2016; Parliament of Sri Lanka, 2015

1 The name of the legislative body in Sri Lanka has been changed over time to the Legislative Council (1833-1931), the State Council (1931-1947), the House of Representatives (1947-1972), the National State Assembly (1972-1978), and the Parliament (1978 up to date). 
Moreover, women in Sri Lanka within all ethnic groups have faced challenges for being actively involved in politics, due to religious barriers and socio-cultural customs. Since most of the Sri Lanka communities are bounded by cultural and religious norms, they limit women movements to a certain extent, mostly to be within homes and to look after their families. Even though the ethnic conflict and the victimization of women made cleavages among communities, and led women to come out of the cultural and religious barriers that dominated their social life, their involvement is mainly in economic and social spheres, and generally not in the political sphere.

Sri Lanka's violent political culture, and the country's situation of conflict that had prevailed for more than three decades up to the end of civil war in 2009, had imposed a number of barriers and challenges to women for actively being involved in politics and elected to the national parliament. In fact, women are the victims of both electoral and ethnic violence in Sri Lanka, and the violent political context did not support women in facing political environments, both physically and mentally. Even though the ethnic conflict and violent political culture caused a few women to become actively involved in politics and achieve higher positions, the majority of the women from all communities were far from being actively involved in politics.

\section{Women Representation in Malaysian Parliament (Dewan Rakyat)}

As a constitutional monarchy, Malaysia has also adopted a system of parliamentary democracy. The prime minister and cabinet ministers were chosen from the parliament composed of two houses elected by the people through general elections held regularly every five years (Azizah, 2002). The Parliament of Malaysia consists of the Senate and the House of Representatives, which have a long history of formation from the British colonial period. The House of Representatives, referred to as Dewan Rakyat, currently consists of 222 members who are elected from a single member consistency through the first-pass-the post system. The senate (Dewan Negara) consists of 70 members who represent the federation states. In this study, only the status and issues of women's representation in Dewan Rakyat were considered for analysis. Moreover, this study covers the parliaments formed from 1955 to 2015. Accordingly, 13 Dewan Rakyats were formed.

Women's role in Malaysian politics has also received attention throughout the world. Compared with other developing countries, Malaysia has been able to elect a considerable number of women representatives to the House of Representatives-Dewan Rakyat. However, when considering women's role with other spheres, their role in politics has been limited to an extent that has made it challenging to elect more women representatives to parliament. Even though politics and representation were very much limited to men's interests during the British colonial rule, with the expansion of the government after independence, political power and influence gradually spread amongst men and women who were either professional bureaucrats or members of political parties in the country.

For the first time in colonial Malaysia, a legislative council, called "Federal Council", was established in 1909 along parliamentary lines for the four Federal Malay States (Parak, Selangor, Pahang and Negeri Sembilan) which was established in 1896. However, in 1948, the "Federal Legislative Council" was established through the "Federation of Malay Agreement", which was reached earlier in the same year. This Federal Legislative Council consisted 75 members (3 ex-officio, 11 from Malay States and the Straits Settlements, 11 British Officials and 50 Unofficial members). This was the first time the legislative council had two-thirds of Unofficial majority. However, this Legislative Council was dissolved in 1955, and a general election was held, in which, for the first time, the people of Malaya went to polls to elect their representatives for the Federal Legislative Council. Then, the members of the council were increased to 98, and among them, 52 were elected through the election (Parliament of Malaysia, 2016). However, only one woman was elected to this legislative council.

The position of women was a talking point for the political elites in the run-up to the 1959 election. All major political parties promised to field more women candidates. But at the federal level, the number of women in parliament did not increase in the following the election. This situation continued even after the 1964 election. However, there has been a gradual increase of women's representation in the successive Dewan Rakyets, with the exception of a sudden decline in 1986.

In the last general election held to the lower house of parliament in 2013, among 222 seats contested, only 23 women were elected. This positioned Malaysia in the second last place in Southeast Asia in terms of women representation in parliament. Women's political representation in Southeast Asia averages about 18 percent, which is below the global average of 22.8 (Inter-Parliament Union, 2016). Representation of women in parliament is highest in Timor-Leste (38.5\%), followed by the Philippines (27.2\%), Laos (25.0\%), Vietnam (24.4\%), Singapore (24.3\%), Cambodia 
(20.3\%), Indonesia (17.1\%), Myanmar (12.7\%), Malaysia (10.4\%) and Thailand (6.1\%) (Inter-Parliament Union, 2016). Despite high female membership rates in political parties, and a very strong women wing in the United Malays National Organization (UMNO), the number of women leaders nominated to stand and elected to office has been dismally low in Malaysia (Mulakala, 2013).

Table 2. Women Members in Parliament (Dewan Rakyat) in Malaysia 1955-2015

\begin{tabular}{|c|c|c|c|}
\hline Election Year & Total members & Women Members & Percentage \\
\hline 1955 & 52 & 1 & 2 \\
\hline 1959 & 104 & 3 & 2.9 \\
\hline 1964 & 104 & 3 & 2.9 \\
\hline 1969 & 144 & 2 & 1.38 \\
\hline 1974 & 154 & 5 & 3.25 \\
\hline 1978 & 154 & 7 & 4.54 \\
\hline 1982 & 154 & 8 & 5.19 \\
\hline 1986 & 177 & 7 & 3.95 \\
\hline 1990 & 180 & 11 & 6.11 \\
\hline 1995 & 192 & 15 & 7.80 \\
\hline 1999 & 193 & 20 & 10.36 \\
\hline 2004 & 219 & 23 & 11 \\
\hline 2008 & 221 & 23 & 10.6 \\
\hline 2013 & 222 & 23 & 10.4 \\
\hline
\end{tabular}

Source: Azizha, 2002; Zakuan 2010; Parliament of Malaysia, 2015.

Women have long been regarded as the backbone of major political parties in Malaysia, such as UMNO and Barisan Nasional (BN). However, the role of women in Malaysian parliament remains limited. Successive elections continued in a repeated pattern that has been in place since independence in this regard (Martin, 2013). When women wings were set up in major political parties, they were expected to strengthen their own organizations and increase party membership. Their existence was expected to facilitate "house-to-house campaigning" rather than to produce potential women candidates. Creating opportunities for women are not seen as being that important by all major political parties. Therefore, women have limited opportunity and access to be elected and represented in parliament. It is also identified by researchers that more female candidates were recruited in elections, but they were not filled in winnable seats. According to Martin (2013), the structure of many political parties in Malaysia allows women only limited opportunities and supports to participate in political processes. Men have thus been able to thrive in and dominate the political sphere. Mulakala (2013) argues that the high level of female education and the democratization of governance process, compared to other countries in the region where this are lacking (e.g. Vietnam and Laos), do not always ensure women's parliament representation in Malaysia. Women's representation in the country remains lower than these countries. She also argues that the family-run political enterprises often serve as a pathway for elite women to participate in politics, leaving little space for ordinary women to emerge as candidates in elections (Mulakala, 2013).

\section{How to Improve Women Representation in Parliaments?}

There are a number of means to accommodate women within the political system and motivate them to be represented in representative bodies, including parliaments. Some of these means are recommended here in order to improve women's representation in parliaments of both selected countries. If governments and political leaders of both countries consider the lack of women's representation as a weakness in their parliament democracy, and are committed to strengthen it, these recommendations would give them at least some guidelines and a framework for further action.

\subsection{Quota system}

Although quota systems have helped many parliaments around the world to increase the number of women, the concept of quotas is not always popular among Malaysian politicians, mainly due to many associating them with the proBumiputera policies. Therefore, the country relies on individual party policies to determine men and women as candidates 
to compete in the general elections. Even though there have been more women in governance and public sectors, increasing public appealing for adopting a 30 percent women quota policy in the national parliament has yet not transformed into law in Malaysia (Rahayu, 2014). The concept of a quota system has also not received the attraction of politicians in Sri Lanka as well. According to Michele Bachelet, Head of UN Women, half of all countries in the world have implemented some form of electoral quota in the past 20 years. Among the 33 countries that have achieved 30 percent of women's representation, 28 have achieved this by implementing gender quotas. In 2011, Prime Minister Najeeb announced that Malaysia would achieve 30 percent female representation on corporate boards within five years. However, no such quota has been set for women's political representation (Quoted by Mulakala, 2013). Despite lobbying efforts from civil society organizations, the potential for Malaysia to boost women's representation remains low.

Similarly, most South Asian countries have implemented legislative measures to ensure women's representation in their legislatures. The initiative of some of these countries such as Afghanistan, Bangladesh and Nepal can be used as examples for regional good practices, as they have taken positive measures in electoral law. However, a simple quota system, specifying the number of women to be elected in parliament should not be the exclusive means to ensure women's representation. It should only be held as a threshold to encourage women's participation in politics and to voice issues pertaining to women. However, the quota system for women's representation needs to be implemented effectively in order to reap the expected results. Sri Lanka is the only country in South Asia without a quota for women's representation in politics.

\subsection{Reforming electoral system}

Electoral systems also play a vital role in determining women's representation in parliament. It is believed that Proportional Representation (PR) is likely to witness more women elected than the first-pass-the post system. Sri Lanka applies the former system, while Malaysia follows the latter. However, both systems have produced less women representation in these countries. In Malaysia, the majoritarian system theoretically limits the probability of women's representation. With a single-member constituency and a majority formula to determine seats, political parties need to put forward their most powerful candidates in order to compete against other parties, especially if the competitor is the incumbent. Therefore, this indicates importance of reform process in the electoral system as to ensure the adequate women representation in parliament in both countries. The opportunity for women to be proposed as candidates solely depends on the internal policy of political parties in Malaysia (Rahayu, 2014). This was also the case in Sri Lankan, even though it practices a PR system with multi-member electoral districts. However, many researchers suggest that multiwinner electoral districts or constituencies increase the chances of women being recruited to run, and to win. Voters also seem to factor in voting for women differently when given the opportunity to vote for more than one seat. Therefore, both countries need to reform electoral policies and practices in order to cater more women candidates, and to increase their winning opportunities in elections.

\subsection{Encouragement from women side / women empowerment}

Both Malaysia and Sri Lanka need to address the mindset of women who are engaged in politics themselves to ensure others too can be involved. Most women who are elected become part of the "male voice", repeating what they say, and not contributing to uplift women's affairs. Women should be encouraged in politics to take up issues with regard to women, and to voice themselves; if this is not the case, these issues will be "swept under the carpet" due to the dominance of males in politics. Furthermore, women who are already in the political sphere need to be encouraged to learn the rules and procedures of the parliamentary system in order to use them effectively and promote their interests and influence decision-making, as this would enable them to compete with men for access to key positions at the decision-making levels. This will also help female politicians to address the lack of self-confidence prevailing among some of them.

\subsection{Cultural change}

Finally, but perhaps most importantly, there must be a cultural change in general politics as well as in electoral politics as to increase women's representation in both countries. Gender audits are useful tools in determining how structures and the environment can become more gender-sensitive so as to encourage more women to be active, as equal participants, and to be represented in public bodies such as parliaments. Similarly, a change of attitudes should also be instilled in 
society towards women entering politics. The concept that "women's representation is vital for societal development and societal peace" must be engrained into the minds of the people, for it is only by treating women in one's society properly can a society as a whole develop. It is a noteworthy fact that patriarchal structures and conservative attitudes are the most important factors that permeate women's political lives in these countries. Therefore, the political environment needs to adopt more gender-sensitive outlooks and policies to help encourage women to take up politics and political representative bodies.

\section{Conclusion}

Even though a democracy refers a people's government, its practice in many modern political systems receives criticism for numerous reasons, the most important of which is its bias against women in terms of accessing democracy. Most democracies throughout the world have failed to represent gender equality in political apparatus. Social democracy was popular for equality, but it too failed to be equal in women's affairs, especially in ensuring their representation in legislative bodies being equal to men. Although there are no legal impediments to the participation of women in politics or governmental affairs, the socio-cultural and religious values limit their involvement in public life. Therefore, in most working democracies, women's representation in parliaments is lower than that of men.

The two selected countries for this research have been practicing parliamentary democracy. However, its practice in both countries varies in many affairs. This research has identified that the matter of women's representation in these two countries is in opposition direction. Malaysia has been able to maintain a considerable percent of women's representation in parliament. On the other hand, even though Sri Lanka has been experiencing universal franchise since 1931; and the country has produced the world's first female Prime Minister, and has been governed by female leaders for about one third of its post-independence parliament democracy era (including the enactment of a number of structural measures), all of these have failed to ensure a reasonable level of women's representation in political institutions, especially in parliament. Male domination in politics, absence of gender quota in elections, violent political culture, impact of ethnic conflict, lack of financial support and political training for women, and socio-cultural barriers, have all collectively contributed to the limited involvement of women, and to their low representation, in the national parliament in Sri Lanka. However, in the case of Malaysia, women leaders were "descendants" of highly educated, wealthy or influential families from rural areas who enjoyed a high professional status, mainly because of their family backgrounds. Women leaders, though few in number, were counterparts of Malay male leaders, and in many instances, they were spouses of men who were already active in politics, and who already had a readymade network of ties and connections with important members of the society (Karim, 1993).

Women in Malaysia have a high potential as leaders of society, but appear to have limited political roles at the national level. No one could deny the active and influential roles of women in societal and economic life in contemporary Malaysia. However, their public political life remains to be limited, and is mainly dominated by men. This has caused the limitation in women's representation in central parliament, to a certain extent. Women's representation in parliament has not reached the level of their public role in socio-economic life. But when compared with Sri Lanka, as a country bounded with religious (Islamic) fundamentals and principles, Malaysia has given a considerable place to women in parliament. However, both countries remain in the lower stage when compared to many other countries in their regional setting, as well as in the global context. It is noteworthy that all successive governments and parliaments in both countries have failed to accept and adopt a comprehensive policy on gender equality in political representation in parliament and local government bodies. Both countries have failed to adopt a form of women quota as to ensure women's representation in parliament, to a considerable extent. It is not an exaggeration to mention that politics has always been a game of men. But through the best possible means, women have to be given a chance to compete with men in the electoral process of parliamentary democracy. The equitable participation of women and men in politics and the government is essential to build and sustain a democracy. A democratic system cannot be truly delivered for all of its citizens if half of the population remains underrepresented in the political arena. Unless the political elites enact measures that will provide more opportunities and support for women in the political realm, it is inevitable that the representation and the roles of women in parliaments will remain limited.

Democracy and equal participation of men and women in the political arena are closely intertwined. No parliament or decision-making body can claim to be representative without the participation and representation of both men and women on a rationale share. As stated in the universal declaration on democracy, the achievement of democracy presupposes a genuine partnership between men and women in the conduct of the affairs of society. 


\section{References}

Azizah, A. (2002). Women in politics: reflections from Malaysia. In International IDEA. Women in parliament. (pp.191-202). Stockholm: International IDEA. [Online] Available: http://www.idea.int/publications/wip/upload/CS_Malaysia_Azizah.pdf (10 th November 2015)

Ballington, J. (2014). Introduction. In J. Ballignton \& A. Karam (Eds.). Women in parliament: beyond number (revised ed.). (pp.23-32). Stockholm, Sweden: International IDEA.

Department of Election, Sri Lanka. (2015). Recognized political parties. [Online] Available: http://52.1.201.50/web/index.php/en/ recognized-political-parties (12 $2^{\text {th }}$ December 2015).

Hirst, P. (1988). Representative democracy and its limits. The Political Quarterly, 59(2), 199-214.

Inter-Parliament Union (IPU). (2016). Women in national parliaments. [Online] Available: http://www.ipu.org/wmn-e/classif.htm (21 January 2016).

Karim, W.J. (1993). Women in politics in Malaysia. In UNESCO. Women in politics: Australia, India, Malaysia, Philippines, Thailand. (p.84-131). Bangkok: Principle Regional Office for Asia and the Pacific. UNESCO.

Kearney, R.N. (1981), Women in politics in Sri Lanka. Asian Survey, 21(7), 729-746.

Kenworthy, L., \& Malam, M. (1999), Gender inequality in political representation: a worldwide comparative analysis. Social Forces, 78(1), 235-268.

Liyanake, K. (1999). Women in political parties: the Sri Lankan experience. In S. Kiribamuna (ed.). Women and politics in Sri Lanka: a comparative perspective. pp.101-142. Kandy: International Center for Ethnic Studies.

Martin, D. (2013). Women's vote in Malaysia. New Mandala. [Online] Available: http://asiapacific.anu.edu.au/newmandala/2013/05/05/ womens-vote-in-malaysia/ (20th December 2015).

Matland, R.E. (1998), Women's representation in national legislatures: developed and developing countries. Legislative Studies Quarterly, 23(1), 109-125.

Mulakala, A. (2013). Where are Malaysia's women politicians?. [Online] Available: http://asiafoundation.org/in-asia/2013/03/13/whereare-malaysias-women-politicians/ (15 th December 2015).

Parliament of Malaysia. (2016). House of representatives: general information. [Online] Available: http://www.parlimen.gov.my/maklumatumum. html?uweb=dr\& (10 January 2016).

Parliament of Sri Lanka. (2015). Lady members of parliament. [Online] Available: http://www.parliament.Ik/handbook_of_parliament/ lady_members.jsp (20th August 2015).

Power, G. (2012). Global parliamentary report: the changing nature of parliamentary representation. Geneva: Inter Parliament Union.

Raaum, N.C. (2005). Gender equality and political representation: a Nordic comparison, West European Politics, 28(4), $872-897$.

Rahayu, R.I. (2014). The success and the barriers to women's representation in South East Asia: between state policies, political parties and women's movements. Jakarta Selatan: Partnership for Governance Reform (Kemitraan Indonesia).

SARSWP. (2013). Women in politics in South Asia. SARSWP Technical Brief. [Online] Available: http://www.eldis.org/vfile/upload/ 1/document/1403/Issue\%2001-\%20Women\%20in\%20politics\%20in\%20south\%20asia3.pdf (15 th December 2015)

Shvedovo, N. (2014). Obstacles to women's participation in parliament. In J. Ballignton \& A. Karam. (Eds.). Women in parliament: beyond number. (revised ed.). pp. 33-51. Stockholm, Sweden: International IDEA.

The National Democratic Institute (NDI). (2015). Gender, Women and Democracy. [Online] Available: https://www.ndi.org/genderwomen-democracy $\left(12^{\text {th }}\right.$ December 2015).

Women under-represented in Malaysian parliament. [Online] Available: http://www.freemalaysiatoday.com/category/opinion/2015/11/14/ women-under-represented-in-malaysian-parliament/ $\left(12^{\text {th }}\right.$ December 2015).

Zakuan, U.A.A. (2010). Women in the Malaysian parliament: do they matter?. Intellectual Discourse. 18 (2), 283-322. 